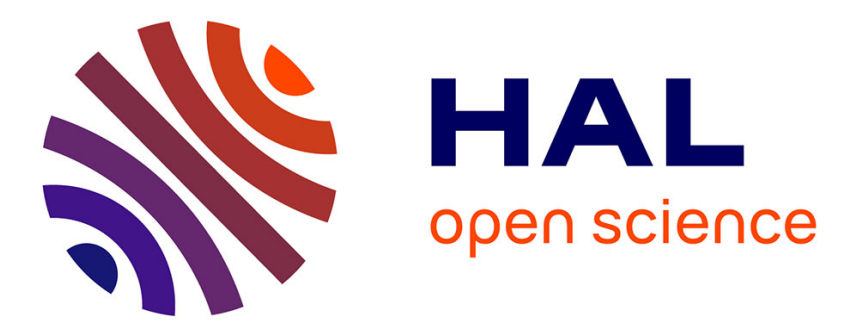

\title{
Shortening of Archaean and Paleoproterozoic continental lithospheres: large strains, but no orogeny
}

Denis Gapais, Jonathan Poh, Philippe Yamato, Thibault Duretz, Florence Cagnard

\section{- To cite this version:}

Denis Gapais, Jonathan Poh, Philippe Yamato, Thibault Duretz, Florence Cagnard. Shortening of Archaean and Paleoproterozoic continental lithospheres: large strains, but no orogeny. European Geosciences Union General Assembly, Apr 2020, online, Austria. pp.EGU2020-1496. insu-02539543

\section{HAL Id: insu-02539543 \\ https://hal-insu.archives-ouvertes.fr/insu-02539543}

Submitted on 8 Dec 2020

HAL is a multi-disciplinary open access archive for the deposit and dissemination of scientific research documents, whether they are published or not. The documents may come from teaching and research institutions in France or abroad, or from public or private research centers.
L'archive ouverte pluridisciplinaire HAL, est destinée au dépôt et à la diffusion de documents scientifiques de niveau recherche, publiés ou non, émanant des établissements d'enseignement et de recherche français ou étrangers, des laboratoires publics ou privés. 
In many ancient deformation belts of Archaean and Paleoproterozoic age (e.g. Terre Adélie in East Antarctica, Finnish Svecofennides in Southern Finland, Murchison Belt in South Africa, Thompson Nickel Belt in Manitoba, Dharwar Craton in western India, Abitibi sub-Province in Québec, Trans-Hudson belt of Canada, Trans-Amazonian belt of Suriname), latest recorded deformations are compressive or transpressive. In these belts that involved hot and weak continental crusts, deformations are distributed with basically vertical tectonics and important crustal thickening. On the other hand, there is no evidence of syn-orogenic extension or late-orogenic collapse, as classically observed in modern orogens where extensional detachments are widespread. Analogue and numerical models emphasize that shortening of weak and hot lithospheres basically favour downward motions, which result in limited topographies. Field evidence further point to metamorphic isogrades rather parallel to the Earth surface at belt scale. Hence, metamorphic conditions are rather monotonous at the scale of individual belts, with limited metamorphic jumps and typical P-T paths with no significant adiabatic retrograde segments. Consistently, localized deep detrital sedimentary basins like foreland or intra-mountain basins, are not documented. Sedimentary records rather suggest distributed sedimentation processes. In addition, several lines of evidence tend to point out that cooling of ancient hot deformation belts was rather slow, which is consistent with distributed topographies and long-lasting erosion-driven exhumation processes. On these bases, we propose that gravity-driven collapse had no reason to occur in ancient hot deformation belts because important topographic gradients and orogeny could not develop as observed in modern mountain chains. 